\section{Dividend month premium in the Korean stock market}

\section{Dividend month premium}

\author{
Bonha Koo
}

Dongguk Business School, Dongguk University, Seoul, Republic of Korea, and

Joon Chae

Department of Finance, Seoul National University, Seoul, Republic of Korea

\begin{abstract}
The dividend month premium is the phenomenon that firms have abnormal returns in predicted dividend month. This study aims to examine the dividend month premium in the Korean stock market, using common stocks listed on the KOSPI and KOSDAQ from January 1999 to December 2016. Abnormal returns are estimated using the following asset price models: capital asset pricing model, Fama-French three-factor model and the Fama-French-Carhart four-factor model. This study finds positive abnormal returns in predicted dividend months, and even for the within-firm portfolio that buys stocks in the predicted dividend months and sells the same stocks in other months. The price impact and the subsequent reversals are greater with lower liquidity and higher dividend yield, implying that the price pressure from dividend-seeking investors affects this dividend month premium. In addition, the anomalies with the pre-declaration stock are smaller than the post-declaration stock, suggesting the necessity to improve the cash dividend policy of postdeclaration for market efficiency.
\end{abstract}

Keywords Market efficiency, Dividend, Dividend month premium, Price pressure

Paper type Research paper

\section{Introduction}

Korean investors have higher uncertainty in cash dividends compared to those in other countries such as the USA. This is because most cash dividends are to be declared ex post facto [1]. As shown in Figure 1, the dividend procedure of the firm whose settlement is at the end of December can be divided into pre-declaration [Figure (1a)] and post-declaration [Figure (1b)]. In pre-declaration, the dividend payment is declared before the ex-dividend date, and the date that determines whether a stockholder is entitled to a dividend payment. Hence, investors can find out in advance whether dividends will be paid for the stocks and decide to trade those stocks before the ex-dividend date. Investors seeking benefits from dividends will buy the shares before the ex-dividend date, while those who are not will sell the shares beforehand. However, in post-declaration, as is the regular disclosure for cash

(C) Bonha Koo and Joon Chae. Published in Journal of Derivatives and Quantitative Studies: 선물연구. Published by Emerald Publishing Limited. This article is published under the Creative Commons Attribution (CC BY 4.0) licence. Anyone may reproduce, distribute, translate and create derivative works of this article (for both commercial and non-commercial purposes), subject to full attribution to the original publication and authors. The full terms of this licence may be seen at http:// creativecommons.org/licences/by/4.0/legalcode

This article is an addition based on the first author's master's thesis from Seoul National University. This work was supported by the Institute of Management Research and the Institute of Finance and Banking at Seoul National University.

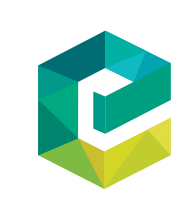

Journal of Derivatives and Quantitative Studies: 선물연구 Vol. 28 No. 2,2020

Emerald Publishing Limited p-ISSN: 1229-988X e-ISSN: 2713-6647 DOI 10.1108/JDQS-04-2020-0006 
JDQS

28,2

78

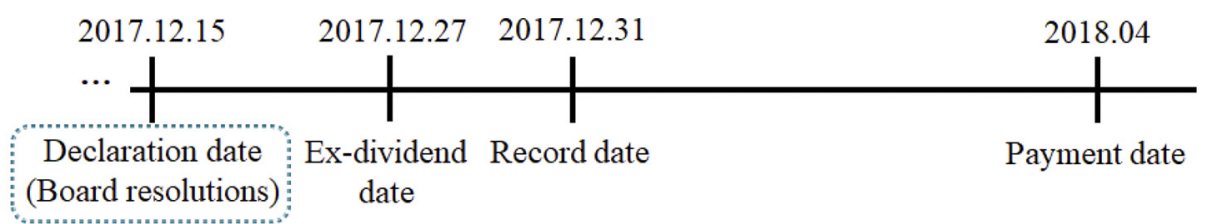

(a)

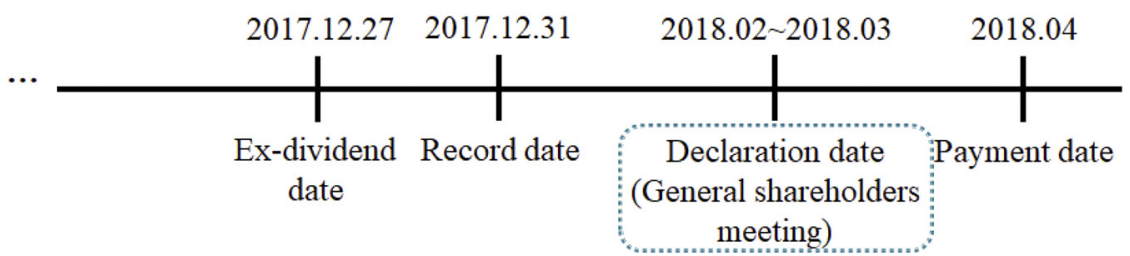

(b)
Figure 1.

Dividend procedure: pre-declaration and post-declaration
Notes: Figure 1 displays the dividend procedure of the firm whose settlement is at the end of December. (a) shows the procedure for pre-declaration. The dividend payment is declared before the ex-dividend date that determines whether a stockholder is entitled to a dividend payment. (b) shows the post-declaration, the regular disclosure for cash dividend in Korea Dividends are declared at the general shareholders' meeting after the ex-dividend date (a) Pre-declaration; (b) post-declaration (regular disclosure for cash dividend in Korea)

dividend in Korea, dividend payments are declared at the general shareholders' meeting after the ex-dividend date. This increases uncertainty among Korean dividend-seeking investors by making dividend-related information unavailable before the ex-dividend date.

However, firms generally pay dividends regularly, allowing investors to predict the dividends for the next period regardless of the timing of the declaration. According to the dividend signaling hypothesis, firms tend to pay dividends continuously because dividend payment has become a means of delivering information about the firm (Arnott and Asness, 2003; Nissim and Ziv, 2001). An analysis of dividend payment trends for our sample, which includes common stocks listed on the KOSPI and KOSDAQ from 1999 to 2016, reveals that the cash dividends are paid in the following period with an $85 \%$ probability if dividends were paid in the past 12 months. If investors can predict dividend payment using the past dividend payment information, excessive profit must not occur in the period in which the dividend is expected. This contradicts the weakform efficient market hypothesis (EMH) (Fama, 1970) [2]. However, studies of the US market provide results that contradict the EMH with respect to dividend prediction (Kalay and Loewenstein, 1985; Hartzmark and Solomon, 2013; Bessembinder and Zhang, 2015). In Korea, there are few studies related to dividend prediction, even though investors are highly dependent on dividend prediction because of the procedural specificity of post-declaration. As an attempt to fill this gap, this study examines whether a dividend month premium exists and determines its cause in the Korean market.

The definition of "predicted dividend months" is of paramount importance because we focus on investors' prediction of dividends. Hartzmark and Solomon (2013) classify the 
dividend type by its frequency based on the Centre for Research in Security Prices' (CRSP) distribution code. They then define predicted dividend months as the month in which the next dividends are expected using its frequency. Because there is no distribution code for dividends in Korea, we classify the dividend frequency type based on the case in which a firm's past dividend payments are made at regular intervals at least twice. That is, dividends are classified as annual for 12-month intervals, semi-annual for six-month intervals and quarterly for three-month intervals. Using this regularity, we define the "predicted dividend months" as the month that the next ex-dividend date is in.

Considering that the abnormal returns on predicted dividend month can be caused by compensation for some risk factor, we examine the risk-adjusted return using a long-short portfolio. We test the dividend month premium using the following asset price models: capital asset pricing model (CAPM), Fama-French three-factor (FF3) model (Fama and French, 1993) and the Fama-French-Carhart four-factor (FF4) model (Carhart, 1997). The long-short portfolio based on predicted dividend month also has abnormal returns. We find a positive risk-adjusted return with all the portfolios that buy on the stocks in the predicted dividend months, and sell:

- all other stocks (between-firms portfolio);

- all other stocks that have paid dividends in the past 12 months (within-firms portfolio); or

- all other stocks that paid dividends one month ago.

The results using a within-firms portfolio indicate that abnormal returns in predicted dividend months are not caused by common risk factors. This is because this portfolio compares the same set of firms in different months. Hence, to describe the dividend month premium as a risk factor, it should be a time-varying risk that becomes riskier only in the predicted dividend months.

As the hypothesis of the dividend month premium, we consider the price pressure, dividend clientele effect, information content effect and earnings announcement effect. First, we analyze the price pressure hypothesis. If the dividend month premium is because of price pressure, abnormal returns should be greater when the investor's transactions have a greater impact on the price because of the high demand for dividends or low liquidity in the stock. Furthermore, there must be return reversals afterward. We find that both the dividend yield and Amihud (2002) illiquidity factor have a positive relationship with the dividend month premium. Also, we find the phenomenon of return reversals, which supports the price pressure hypothesis.

Second, to analyze the dividend clientele effect and the information content effect, we test the daily return on the ex-dividend date and the dividend declaration date within the predicted dividend months, respectively. The results show that there is a significant return on these dates, which indicates that the aforementioned effects may exist. However, the impact of these dates is only $30 \%$ of the total dividend month premium. This can be interpreted as the occurrence of abnormal returns throughout the predicted dividend months, rather than focused on the ex-dividend date or declaration date. A significant price reversal occurs afterward, suggesting that the dividend month premium is generated by investors' price pressure rather than the dividend clientele effect or information content effect.

Third, to control for the earnings announcement effect, we analyze the risk-adjusted return of predicted dividend months only when an earnings announcement event is not included in that month. The results show that the predicted dividend months have abnormal positive returns, even after eliminating the announcement effect. Also, we examine the dividend month premium by the dividend frequency types. The results indicate that the pattern of abnormal returns is linked to the frequency of the dividend. We find the abnormal returns 12 months after dividend 
JDQS 28,2

payment for annual dividends, six months after dividend payment for semi-annual dividends and three months after dividend payment for quarterly dividends. This demonstrates that the dividend month premium is affected by the event of dividend payment itself.

Fourth, to analyze the effect of dividend procedure, we test the dividend month premium by separating the predicted dividend months into post- and pre-declaration. We find that pre-declaration stocks have abnormal returns in the predicted dividend months. The evidence of dividend month premium for pre-declaration stocks, which can predict the next dividend payment more clearly, indicates the violation of weak-form EMH. The results for the post-declaration stocks show higher abnormal returns in the predicted dividend months compared to the pre-declaration stocks. This broadly suggests that the post-declaration procedure leads to investors' uncertainty and thereby increases the dividend month premium.

The analysis by stock characteristics suggests that higher the number of dividends paid consecutively in the past, smaller the abnormal return in predicted dividend months. Also, the dividend month premium gets larger if the stock's age is lesser, its size is smaller and its book-to-market ratio is higher. Overall, this suggests that stocks with higher liquidity have smaller dividend month premiums, which supports the price pressure hypothesis.

We find that stocks have abnormal positive returns in months when they are predicted to issue a dividend and that subsequent price reversals occur. This suggests that investors can exploit the dividend month premium using long-short portfolios. Also, the dividend month premium is larger for companies with lower liquidity or higher dividend yield. This indicates that the dividend month premium is caused by price pressure from dividendseeking investors. In particular, firms with post-declaration of dividend payments have higher abnormal returns than pre-declaration. This indicates that the anomalies get larger with the specificity of the Korean cash dividend system, that is, post-declaration. These results imply that stocks should be subject to a pre-declaration procedure for cash dividends to reduce uncertainty in investors' decision-making and increase market efficiency.

The rest of this study is organized as follows. Section 2 establishes the research hypotheses. Section 3 describes the data and methodologies. Section 4 outlines the empirical results. Section 5 presents the conclusion of this study.

\section{Literature review and related hypotheses}

According to the dividend signal hypothesis, firms are reluctant to omit dividends because the return will be reduced if the declaration is delayed or dividends are omitted (Nissim and Ziv, 2001). Thus, an investor who knows the past timing of dividend payments can predict the dividend payments that may follow in the foreseeable future. If the dividend payment of the stock is predictable using past information, the abnormal return of predicted dividend months is a result that contradicts the weak-form EMH. However, a previous study of the US stock market regarding dividend prediction suggests a contrary result to EMH. Kalay and Loewenstein (1985) show that average returns and systematic risks are abnormally high at the time of the dividend announcement, even though dividends are regularly issued. This suggests that an increase in systematic risk is not sufficient to account for abnormal returns. Hartzmark and Solomon (2013) find significant abnormal returns in the month in which cash dividends are expected. They argue that price pressure from dividend-seeking investors causes this anomaly. Bessembinder and Zhang (2015) also find significant abnormal returns using trading strategies that purchase stocks at a time when most corporate distribution events such as stock split, stock dividends, special dividends or dividend increase are highly likely, even though it is easy to predict the next event. Table 1 


\begin{tabular}{|c|c|c|c|c|}
\hline & Price pressure & Clientele effect & Information content effect & Jividend \\
\hline Related date & $\begin{array}{l}\text { Predicted dividend } \\
\text { month }\end{array}$ & Ex-dividend date & Declaration date & premium \\
\hline $\begin{array}{l}\text { Effect on return (short- } \\
\text { term) }\end{array}$ & Increase & Increase & Increase & \\
\hline $\begin{array}{l}\text { Effect on return (long- } \\
\text { term) }\end{array}$ & No change (reversal) & Change & Change & 81 \\
\hline View on EMH & Valid in the long term & Valid & Valid & \\
\hline Main content & $\begin{array}{l}\text { Price pressure from } \\
\text { dividend-seeking } \\
\text { investors increases prices } \\
\text { in the short term, but } \\
\text { later prices adjust to the } \\
\text { original equilibrium price } \\
\text { (reversal) }\end{array}$ & $\begin{array}{l}\text { On the ex-dividend date, } \\
\text { transactions between } \\
\text { investors with different } \\
\text { marginal tax rates } \\
\text { fluctuate the demand for } \\
\text { stocks, which lead the } \\
\text { long-term effects }\end{array}$ & $\begin{array}{l}\text { Because dividend disclosure } \\
\text { includes information about } \\
\text { the future value of the firm, } \\
\text { this is a signal for intrinsic } \\
\text { value and has long-term } \\
\text { effects }\end{array}$ & $\begin{array}{r}\text { Table } 1 . \\
\text { Hypotheses related to }\end{array}$ \\
\hline Related literature & $\begin{array}{l}\text { Hartzmark and Solomon } \\
\text { (2013) }\end{array}$ & $\begin{array}{l}\text { Elton and Gruber (1970), } \\
\text { Brennan (1970) }\end{array}$ & $\begin{array}{l}\text { Kalay and Loewenstein } \\
\text { (1985), Savor and Wilson } \\
\text { (2016) }\end{array}$ & $\begin{array}{r}\text { dividend month } \\
\text { premium and market } \\
\text { reaction }\end{array}$ \\
\hline
\end{tabular}

shows the hypothesis related to dividend month premium and market reaction. Here, we mainly analyze the price pressure, dividend clientele effect and information content effect.

\subsection{Price pressure}

Price pressure is based on the model that a stock has a perfectly elastic demand curve in the long term, while it has a downward-sloping demand curve in the short term. If dividend-seeking investors outnumber dividend-avoiding investors, and arbitrageurs fail to provide sufficient liquidity to the market, then excess demand for shares temporarily increases prices. There is no perfect substitute for stocks because of its uniqueness, resulting in changes in share prices in the short term if a particular stock pays dividends. However, because dividend payments are unrelated to intrinsic firm value, prices adjust to the original equilibrium price (Miller and Modigliani, 1961). That is, according to the price pressure hypothesis, share prices react to price pressure temporarily, but later price reversal occurs.

We cannot claim that investors buy stocks immediately before the ex-dividend date and sell them immediately thereafter because of price pressure. However, investors can accelerate buying the stocks that they were already willing to buy before the ex-dividend date and delay selling the stocks that they were already willing to sell thereafter. If the price pressure from dividend-seeking investors causes the dividend month premium, the abnormal return should be generated until dividend payment. Also, there should be return reversals because investors will sell their shares after the dividend payment.

The price pressure gets greater with lower liquidity or higher dividend yield [3]. An increase in demand for dividends increases the demand for dividend-paying assets before the ex-dividend date, even if the investor is not actively inclined to buy and sell assets in the short term. In other words, if investors prefer dividends because of dividend catering or the marginal tax rates, they are more likely to prefer companies that pay larger dividends and it causes the price pressure. Also, the lack of liquidity amplifies the price pressure. Thus, the following hypotheses are derived: 
H1-1. Return reversal exists after the dividend month premium.

H1-2. The dividend month premium and liquidity have a negative relationship.

H1-3. The dividend month premium and demand for dividends have a positive relationship.

\subsection{Dividend clientele effect}

Dividend clientele theory is based on the investors' preference for certain stocks because of the differential tax treatment of dividends and capital gains. For example, investors with low (high) marginal tax rates prefer stocks with a high (low) dividend-payment ratio. Previous literature has mainly focused on the stock price reaction on the ex-dividend date. Generally, long-term investors who hold shares have two choices regarding the timing of share selling before and after the ex-dividend date. First, selling stocks just before the exdividend date would result in selling at a price higher than the dividend price, which would result in capital gains higher than the difference amount. However, dividends must be given up. On the other hand, selling on the ex-dividend date reduces capital gains because of lower dividend prices but results in dividends being earned. Thus, transactions occur between investors with different marginal tax rates on the ex-dividend date, which changes the demand for shares before and after the dividend payment.

Elton and Gruber (1970) argue that the differential tax rate between capital gains and dividend income results in the share price falling below the dividend amount at the exdividend date. Brennan (1970) demonstrates that if a higher tax rate is applied to dividend income than to capital gains, the investor should be compensated for the tax disadvantages. They argue that risk-adjusted return should increase as dividend yield increases. In addition, risk-adjusted returns should be concentrated on the ex-dividend date. That is, for the dividend clientele effect hypothesis to hold, higher dividend yield should lead to a higher risk-adjusted return on the ex-dividend date. Because this phenomenon is caused by fluctuations in stock demand by investors with different marginal tax rates, there should not be any subsequent price reversal. Accordingly, $H 2$ is derived as follows:

H2-1. The dividend month premium should be concentrated on the ex-dividend date.

H2-2. The dividend month premium and dividend yield should have a positive relationship, and this effect should continue and not result in a price reversal.

\subsection{Information content effect}

The information content effect is the view that dividend policies can be used to convey superior information about the firms when there are information asymmetries (Lintner, 1956). Consequently, if there is a change in a firm's dividend policy, it is usually interpreted as a change in the manager's predictions about the firm's future profitability. The share price fluctuates because of information about the future firm value rather than the payment of the dividend. The empirical analyses of the information content effect of dividends are mainly conducted to verify the existence of abnormal returns at the dividend declaration date. For example, Kalay and Loewenstein (1986) show an abnormally high return and systematic risk at the date of dividend declaration. For the information content hypothesis to hold, abnormal returns from the predicted dividend months must be concentrated on a dividend declaration date. In addition, there should not be subsequent price reversal because the dividend declaration contains information that affects intrinsic value. 
In addition to dividend declaration, other information related to firms may affect the predicted dividend months. Typically, earnings announcement makes firms more exposed to macro-economic risks, resulting in higher returns (Savor and Wilson, 2016) [4]. If the predicted dividend months coincide with the earnings announcement month, the premium is attributable to the earnings announcement effect (Beaver, 1968). Therefore, if the earnings announcement premium causes an anomaly in the predicted dividend months, the abnormal return should disappear when the firm-month with the earnings announcement event is excluded in the predicted dividend months. If there is a risk-adjusted excess return in predicted dividend months even after controlling for the earnings announcement, the earnings announcement effect hypothesis can be rejected. Therefore, $H 3$ is derived as follows:

H3-1. The dividend month premium will be concentrated on the dividend declaration date.

H3-2. The dividend predicted months that coincide with earnings announcement months have higher returns.

\section{Data and methodology}

\subsection{Data}

We analyze the cash dividends of common stocks listed on the KOSPI and KOSDAQ from January 1999 to December 2016. The data on daily stock returns and the event dates related to the dividends are obtained from FnGuide (www.fnguide.com). We exclude REITs, SICs, Infra Fund, Invest. Company and ETF shares, as well as shares less than 1,000 won and whose prices from the previous month are not observed. In the case of dividend samples, only cash dividends are considered, excluding cases where the face value of the dividend is less than 500 won. We use the dividend-adjusted return and winsorize at the 1\% and 99\% level.

Regarding the predicted dividend months, Hartzmark and Solomon (2013) classify the dividend frequency type based on CRSP distribution code and define month-t as the predicted dividend months in the following cases: if a firm pays:

- the quarterly dividends in the months $\mathrm{t}-3, \mathrm{t}-6, \mathrm{t}-9$ or $\mathrm{t}-12$;

- semi-annual dividends in the month $\mathrm{t}-6$ or $\mathrm{t}-12$; and

- annual dividends in the month t-12.

However, considering there is no clear classification for dividend frequency type in Korea, we classify the dividend frequency type based on a stock's past dividend intervals, including interim dividends and fiscal-year dividends. If past dividends are made at regular intervals at least twice for each stock, the dividend frequency type is classified into quarterly, semi-annual, annual or unknown (for dividends that do not fall under the aforementioned but are regular). Specifically, we classified dividend type into quarterly if the firm paid dividends $t-3$ and $t-6$ month, and define the month-t as the predicted dividend months for this firm. Similarly, if there were ex-dividend dates at t- 6 and $t-12$, then the month- $t$ is the predicted dividend months and it is classified into semi-annual dividends. If there were ex-dividend dates at t-12 and t-24 (12-month interval), then the month-t is the predicted dividend months and the classification is semi-annual dividends. For example, for a firm whose past two ex-dividend date is June 2015 and December 2015, June 2016 is designated as the firm's predicted dividend months because the next dividend is expected in 
JDQS 28,2

that month. If the ex-dividend date occurs in December 2011 and December 2012, December 2013 is designated as the predicted dividend month. Accordingly, even for the same firm, the types of dividends are classified differently depending on the continuity of dividend payments in the past. However, non-repeated dividends whose dividend type could not be determined are excluded. When measured with monthly data, it is easy to regressively analyze various risk factor models to obtain expected returns, and a clear interpretation of the asset price theory or anomaly is possible for this value. In Korea, the declaration of dividends occurs about 2-3 months after the ex-dividend date, so the advantage is that the declaration date is not reflected even if the predicted dividend months is defined as the month in which the next ex-dividend date is expected.

The earnings announcement date for each stock is collected to identify the earnings announcement effect on the dividend month premium. Following Baik et al. (2012), we define earnings announcement date as the earliest date among:

- preliminary earnings announcement dates under the title of fair disclosure;

- material change disclosure dates; and

- the date of shareholder meeting announcement.

The earnings announcement date of the firms that are subject to analysis is collected through KIND (http://kind.krx.co.kr/), an electronic disclosure system of the Korea Exchange. The sample included the earnings announcement dates of 1,090 firms and 13,190 firm-months. However, only 122 firm-month of earnings announcement date is included in the predicted dividend months. This is because the predicted dividend months are mostly distributed in June and December, and more than half of the earnings announcement dates are distributed in February and March.

We present summary statistics in Table 2. Based on whether the firm paid a dividend in the past 12 months, Panel A displays characteristics of 1,208 firms that paid cash dividends at least once in the past 12 months, whereas Panel B shows characteristics of 1,402 firms that did not pay cash dividends in the past 12 months. Panel $\mathrm{C}$ describes the persistence of 14,519 cash dividends which can identify its frequency type. The $84.70 \%$ of firm-month paid some cash dividend in the past 12 months, which presents the continuity of payment of cash dividends. Also, about $82 \%$ of cash dividends are paid annually, and it is indicated that most dividends in Korea are paid as annual dividends, and their sustainability is very high at $92 \%$.

We analyze how average returns vary based on the timing of past dividends to examine whether the dividend is highly profitable in the month in which dividends are expected (Table 3$)$. The portfolio of " $N$ months after dividend payment" includes stocks that $N$ months have passed from the month that includes the ex-dividend date. "All dividends" refer to all cash dividends and "Annual dividends" refer only to cash dividends with yearly frequency. As shown in Table 2, dividend frequency is mostly annual, hence, for a premium to occur in the month in which dividends are expected, the expected return " 12 months after dividend payment" should be high and the standard deviation should be low. The results in Table 3 show that " 12 months after dividend payment" has the highest average return $(3.71 \%)$ and the lowest standard deviation $(10.57 \%)$ compared to other periods. This suggests that the next dividend payment is sufficiently predictable based on the timing of past dividend payments.

Table 4 shows the distribution of average return for the predicted dividend months, all other firms with a dividend in the past 12 months but are not predicted to pay in that month and all other firms with no dividend in the past 12 months but are not predicted 


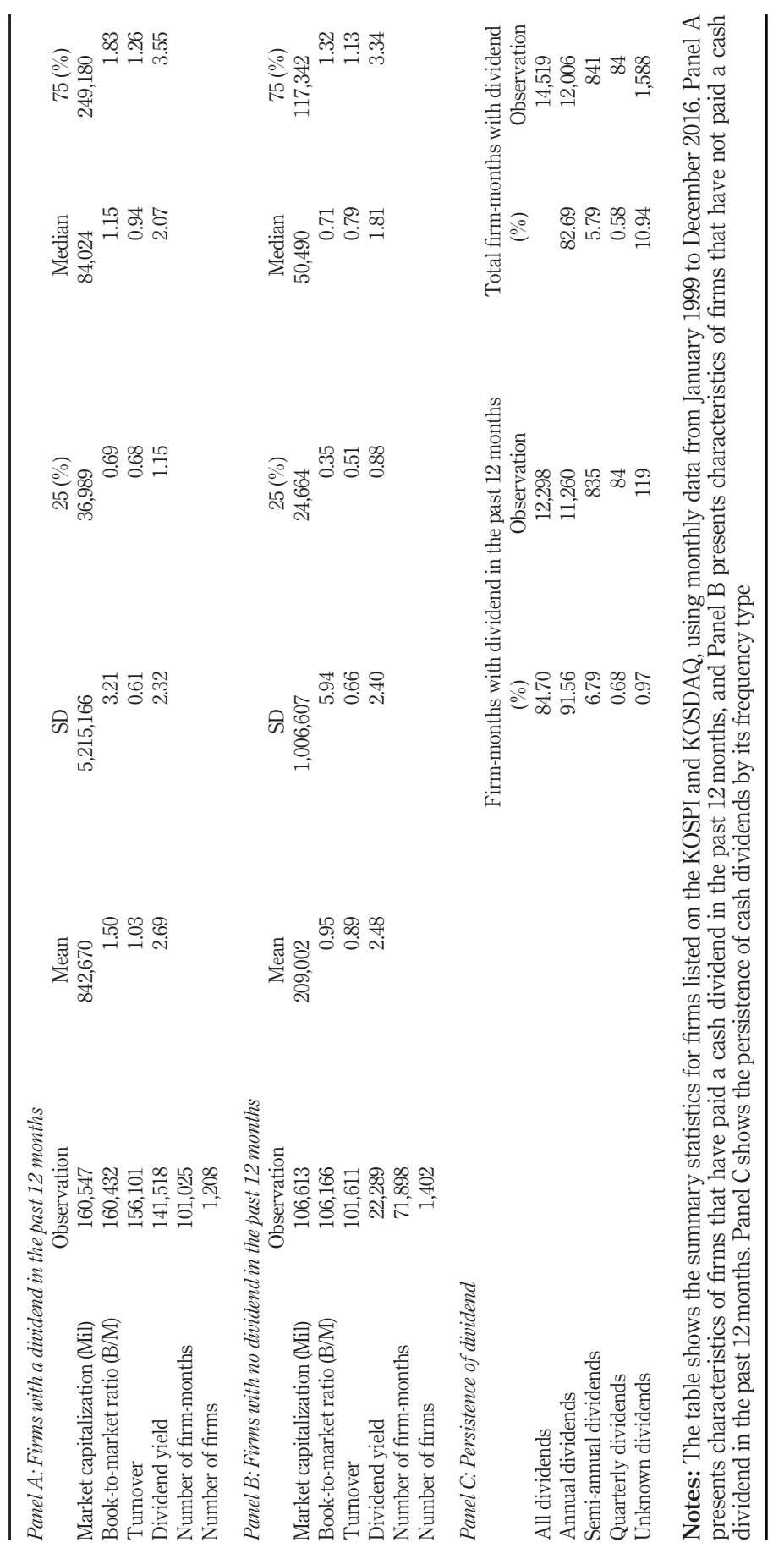

Dividend month premium

85

Table 2. Summary statistics 


\begin{tabular}{|c|c|c|c|c|c|}
\hline \multirow{2}{*}{$\begin{array}{l}\text { JDQS } \\
28,2\end{array}$} & \multirow[b]{2}{*}{$N$ months after dividend payments } & \multicolumn{2}{|c|}{ Returns (\%) } & \multicolumn{2}{|c|}{ Probability of dividend $(\%)$} \\
\hline & & Mean & SD & All dividends & Annual dividends \\
\hline \multirow{12}{*}{86} & 1 & 0.31 & 12.21 & 0.01 & 0 \\
\hline & 2 & 3.25 & 11.66 & 0 & 0 \\
\hline & 3 & 2.79 & 11.63 & 0.82 & 0.02 \\
\hline & 4 & 3.51 & 12.40 & 0.02 & 0 \\
\hline & 5 & 0.38 & 12.33 & 0.04 & 0 \\
\hline & 6 & -0.31 & 11.26 & 7.59 & 0.4 \\
\hline & 7 & 1.75 & 11.53 & 0.01 & 0.01 \\
\hline & 8 & -0.43 & 11.61 & 0.01 & 0.01 \\
\hline & 9 & 1.41 & 11.82 & 0.78 & 0.09 \\
\hline & 10 & 0.48 & 11.79 & 0.02 & 0 \\
\hline & 11 & 1.31 & 12.26 & 0.01 & 0.01 \\
\hline & 12 & 3.71 & 10.57 & 90.7 & 84.27 \\
\hline
\end{tabular}

Table 3.

Raw return and the probability of dividend payment
Notes: The table presents the raw returns and the probability of dividend payments based on the timing of past dividends, using monthly data from January 1999 to December 2016. The portfolio of " $N$ months after dividend payment" includes stocks that $N$ months have passed from the month that includes the exdividend date. "All dividends" refer to all cash dividends and "Annual dividends" refer only to cash dividends with yearly frequency.

\begin{tabular}{|c|c|c|c|c|c|c|c|c|c|c|}
\hline & $\begin{array}{l}\text { Average } \\
\text { return }\end{array}$ & $\mathrm{SD}$ & $\begin{array}{l}\text { Sharpe } \\
\text { ratio }\end{array}$ & $1(\%)$ & $5(\%)$ & $\begin{array}{c}25 \\
(\%)\end{array}$ & Median & $\begin{array}{c}75 \\
(\%)\end{array}$ & $\begin{array}{c}95 \\
(\%)\end{array}$ & $\begin{array}{l}99 \\
(\%)\end{array}$ \\
\hline $\begin{array}{l}\text { (1) Predicted dividend } \\
\text { month } \\
\text { (2) All other firms with }\end{array}$ & 3.72 & 10.57 & 0.33 & -20.39 & -12.36 & -2.46 & 2.92 & 8.89 & 22.46 & 37.70 \\
\hline $\begin{array}{l}12 \text { months } \\
\text { (3) All other firms with }\end{array}$ & 1.34 & 12.26 & 0.09 & -25.27 & -17.41 & -6.19 & 0.23 & 7.64 & 23.86 & 38.89 \\
\hline $\begin{array}{l}\text { no dividend in the past } \\
12 \text { months } \\
\text { (4) Long(1) and short(2) }\end{array}$ & 0.62 & 14.53 & 0.02 & -27.84 & -21.22 & -8.97 & -0.79 & 8.36 & 28.71 & 42.72 \\
\hline $\begin{array}{l}\text { portfolio } \\
\text { (5) Long(1) and short(3) }\end{array}$ & 1.1 & 5.49 & 0.14 & -12.14 & -7.49 & -1.27 & 0.64 & 2.65 & 11.44 & 17.79 \\
\hline portfolio & 2.45 & 5.61 & 0.38 & -13.19 & -6.65 & -0.29 & 2.55 & 4.58 & 12.92 & 15.07 \\
\hline
\end{tabular}

Table 4.

Returns on predicted dividend month
Notes: The table reports the average returns of portfolios of (1) predicted dividend months, (2) firms that paid a dividend in the past 12 months but are not predicted to pay in that month and (3) firms that did not pay a dividend in the past 12 months but are not predicted to pay in that month. The long-short portfolios are described in (4) and (5). The average return is the time-series average values for portfolios, formed by aggregating firms of each month

to pay in that month. The results show that the predicted dividend months have the highest average return of $3.72 \%$, and the lowest standard deviation of $10.57 \%$. Also, it has the highest Sharpe ratio [5], which implies that investor who invests in the stocks with predicted dividend months can earn a higher return for a given risk. We also describe the summary statistics for a long-short portfolio. The average return is the time-series average values for portfolios, formed by aggregating firms of each month. The results show that all of the difference portfolios have excess returns. 


\subsection{Methodology}

3.2.1 Return in the predicted dividend months. Concerning that the dividend month premium may be caused by compensation for some risk factor, we first form a simple longshort difference portfolio and then calculate the risk-adjusted return.

We use a long-short portfolio because the impact of systematic risk is larger for betweenfirm analysis, but is weaker for the within-firm portfolio. The analysis within a set of firms in different months could result in less exposure to the risk factor that is constant over time. The long-short portfolio consists of three main categories:

(1) buying predicted dividend months and selling all other firms that are not expected to pay dividends in that month (short1), which refers to between-firms portfolio;

(2) buying the predicted dividend months and selling other firms that paid dividends over the past year but are not expected to pay dividends in that month (short2), which refers to the within-firm portfolio; and

(3) buying the predicted dividend months and selling the firms which pay dividend one month ago (short3).

The summary statistic of Table 2 displays that firms that paid dividends in the past 12 months have a larger size and a higher book-to-market ratio compared to non-dividend payers. This means that dividend-paying firms are more likely to be exposed to systematic risks in terms of the FF3 model than non-dividend paying firms. To identify whether the cause of the dividend month premium can be explained by common risk, we mainly use the FF4 regression model using equation (1):

$$
\begin{aligned}
\mathrm{R}_{\text {predDiv }, \mathrm{t}}-R f_{t}= & \alpha+\beta_{M k t-r f} * M k t \_r f_{t}+\beta_{S M B} * S M B_{t} \\
& +\beta_{H M L} * H M L_{t}+\beta_{M O M} * M O M_{t}+\epsilon_{t}
\end{aligned}
$$

where $\mathrm{R}_{\text {predDiv,t }}$ refers to the stock return in month $t$ in which dividends are predicted and $R f_{t}$ is the risk-free interest rate of month $t$. $M k t_{-} v f_{t}, S M B_{t}, H M L_{t}$ and $M O M_{t}$ represent excess market return, small minus big (size factors), high minus low (B/M factors) and up minus down (momentum factors). $\alpha(A l p h a)$ refers to the abnormal returns which cannot be explained by common risk factors. Both equal-weighted and value-weighted portfolios are formed. We also conduct the analysis based on the CAPM model (Mkt_rf) and the FF3 model (Mkt_rf, SMB and $H M L)$.

We also set liquidity risk as a systematic factor in some cases. Investors want higher compensation because low-liquidity stocks have relatively higher price shock costs compared to those with higher liquidity (Amihud and Mendelson, 1986). Thus, we examine the risk-adjusted returns in the predicted month after controlling five factors, that adds Pástor and Stambaugh (2003) liquidity factors ( $L I Q)$ to the FF4 factors ( $M k t \_r f, S M B, H M L$, $M O M$ and $L I Q)$.

3.2.2 Hypothesis of the predicted dividend months. Concerning the dividend clientele hypothesis and information content hypothesis, we try to examine the daily abnormal returns relative to the FF4 model on the particular event period related to the dividends, the predicted ex-dividend date, the (actual) ex-dividend date and declaration date. Also, we analyze the cumulative abnormal return over 20 days after the ex-dividend date (one day after the ex-dividend date to the next 20 business days) to find evidence of return reversal.

Also, we test the relationship between risk-adjusted return and the liquidity, regarding H1-2. For measures of liquidity, we use the Amihud (2002) illiquidity factor (ILLIQ ${ }_{i t}$ ) and the 
JDQS 28,2

period between dividend declaration and ex-dividend date $\left(\right.$ Interim $\left._{i, t}\right)$. The illiquidity factor (Amihud, 2002) is calculated using equation (2).

$$
\mathrm{ILLIQ}_{i \mathrm{it}}=\frac{1}{D_{i t}} \sum_{d=1}^{D_{t}} \frac{\left|R_{i t d}\right|}{V O L_{i t d}} * 10^{6}
$$

where $R_{i t d}$ refers to the daily return of stock $i$ at day $d, \mathrm{VOL}_{\text {itd }}$ to the volume of stock $i$ at day $d$ and $D_{i t}$ to the number of days in which stock $i$ is traded during month $t$. The stocks with low (high) ILLIQ refer to stocks with high (low) liquidity.

We analyze whether illiquidity factors are linked to the dividend premium using the two steps, following Brennan et al. (1998). After estimating the residual values for a regression based on the FF4 model, we regress the residuals on the illiquidity factor [6]. Especially, we run a backward rolling windows regression for the past year, or [t-250-t-1] business days using daily return [7]. The estimates of each beta $\left(\widetilde{\beta_{i, t}^{M K T}}, \widehat{\beta_{i, t}^{S M B}}, \widetilde{\beta_{i, t}^{H M L}}, \widetilde{\beta_{i, t}^{M O M}}\right)$ and the residuals $\widetilde{\varepsilon_{i, t}}$ are calculated using equation (3).

$\widetilde{\epsilon_{i, t}}=\left(R_{i, t}-R_{f, t}\right)-\widetilde{\beta_{i, t}^{M K} T} * M k t_{r f t}-\widetilde{\beta_{i, t}^{S M B}} * S M B_{t}-\widetilde{\beta_{i, t}^{H M L}} * H L_{t}-\widetilde{\beta_{i, t}^{M O M}} * M O M_{t}$

where $\widetilde{\varepsilon_{i, t}}$ indicates the t-day residual of $i$ shares, which indicates the returns not explained by the FF4 risk factor. $R_{i, t}$ is the return of stock $i$ for day $t$ and $R f_{t}$ is the t-day risk-free interest rate. Because the sample is from 1999, $\widetilde{\varepsilon_{i, t}}$ is calculated from January 1 , 2000.

Using these residuals, we test the relationship between the illiquidity factor and the residuals. We run a regression analysis with $\widetilde{\varepsilon_{i, t}}$ as a dependent variable and $I L L I Q_{i, t}$ as an explanatory variable, as shown in equation (4).

$$
\widetilde{\boldsymbol{\epsilon}_{i, t}}=\widetilde{\alpha_{i, t}} \widetilde{I L I Q}+\gamma_{i, t} * I L L I Q_{i, t}+\widetilde{u_{i, t}}
$$

The second liquidity indicator is the interim period from the dividend disclosure date to the ex-dividend date. The shorter the interim period, the less trading time for investors. This raises the price pressure because of liquidity shortages and increases abnormal returns. This is because the dividend-seeking investor is willing to buy stocks between the dividend declaration date and the ex-dividend date rather than buying earlier and holding more than necessary (Hartzmark and Solomon, 2013). This price pressure hypothesis using the interim period is valid only with pre-declaration whose ex-dividend date arrives after the dividend declaration. Thus, we consider the 531 firm-months that implement pre-declaration when testing with the interim period. We test this using equation (4) where $I L L I Q_{i, t}$ is replaced with Interim $_{i, t}$, the natural log for the number of days between ex-dividend and dividend declaration.

Regarding H1-3, we test the relationship between the predicted dividend months and the investor's demand for dividends. We use the dividend yield as a proxy for dividend demand. The higher the dividend yield, the higher the demand of dividend-seeking investors (Harris et al., 2015). Dividend yield ( Divyil $_{i, t}$ ) is calculated as the average cash dividend payment from the previous 12 months, divided by the stock price from the previous month. We test this using equation (4) where $I L L I Q_{i, t}$ is replaced with Divyil $_{i, t}$. 
Finally, about $H 1-1$, we analyze whether there are return reversals after dividends are paid. To find evidence of return reversal, we calculate the cumulative 20-day abnormal returns the day after the ex-dividend date and the monthly abnormal returns before and after the dividend payment.

Dividend month premium

\section{Empirical results}

\subsection{Dividend month premium}

Table 5 reports the results of regression using equation (1) to identify the abnormal returns for predicted dividend month after controlling common risk factors. Panel A of Table 3 shows positive abnormal returns after controlling FF4 factors in the portfolios of predicted dividend months. The equal-weighted portfolio had an economically and statistically significant alpha of $3.95 \%(t$-values $=4.24)$ per month. The long-short portfolio for betweenfirm analysis (long-short1) and within-firms analysis (long-short2) has a statistically significant positive alpha of $2.93 \%(t$-values $=3.10)$ and $2.87 \%(t$-values $=3.04)$, respectively. The results with a long-short portfolio using within-firms analysis suggests that dividend premiums are not caused by common risk factors or by other factors that remain constant over time. The alpha of short 3 portfolio is $-2.23 \%$, which suggests that the firms who pay dividend one month ago have the negative abnormal returns, which agrees with the price pressure hypothesis that dividend-seeking investors want to sell their shares after receiving the dividend. The long-short portfolio with the short3 portfolio also has significant abnormal returns $(4.39 \%)$. For the value-weighted average value, the results are similar. Panels B and C show the effects are similar under FF3 and CAPM models of monthly excess return. This indicates that the dividend month premium is not caused by common risk factors.

Table 6 presents the intercepts for regressions of excess returns on liquidity factor and the FF4 factors (Mkt_rf, SMB, HML, MOM and $L I Q)$. We find abnormal returns in the predicted dividend months after controlling a liquidity factor. The within-firm portfolio has a significant alpha for the within-firm portfolio of $2.49 \%(t$-values $=2.41)$ in Panel B. In particular, it has an insignificant factor loading on $S M B, H M L, M O M$ and LIQ. This is because the within-firm portfolio has less exposure to the risk factor that is constant over time. Assuming that the FF4 and liquidity factors reflect all reasonable risk factors, the five risk factors suggest a lack of explanation for the dividend month premium in the Korean stock market. This suggests that the dividend month premium is unlikely to be a risk premium for omitted latent risk factors.

\subsection{Hypothesis of dividend month premium}

4.2.1 Price pressure hypothesis. We examine the risk-adjusted returns in a particular event period related to the dividends, the predicted dividend date, the ex-dividend date, declaration date and the 20 days after the ex-dividend date in Panel A of Table 7. The daily FF4 regressions of stock returns are conducted separately for each period. The actual exdividend date and declaration date have a highly significant risk-adjusted return of $1.09 \%$ and $1.38 \%$, respectively. Also, the next 20 days after ex-dividend have a risk-adjusted cumulative return of $-4.62 \%$ (significant at the $5 \%$ level), indicating price reversal. These results are consistent with the price pressure regarding H1-1.

Table 7 also shows the relationship between daily risk-adjusted returns and the characteristic of firms using equations (3) and (4). The independent variable is Amihud (2002) illiquidity factor $\left(I L L I Q_{i, t}\right)$ in Panel B. There are significant positive abnormal returns on the predicted dividend date, ex-dividend date and dividend declaration, respectively. It also shows the return reversals after 20 days. Moreover, we find that the coefficient of 
JDQS

28,2

90

Table 5.

Risk-adjusted returns in predicted dividend month

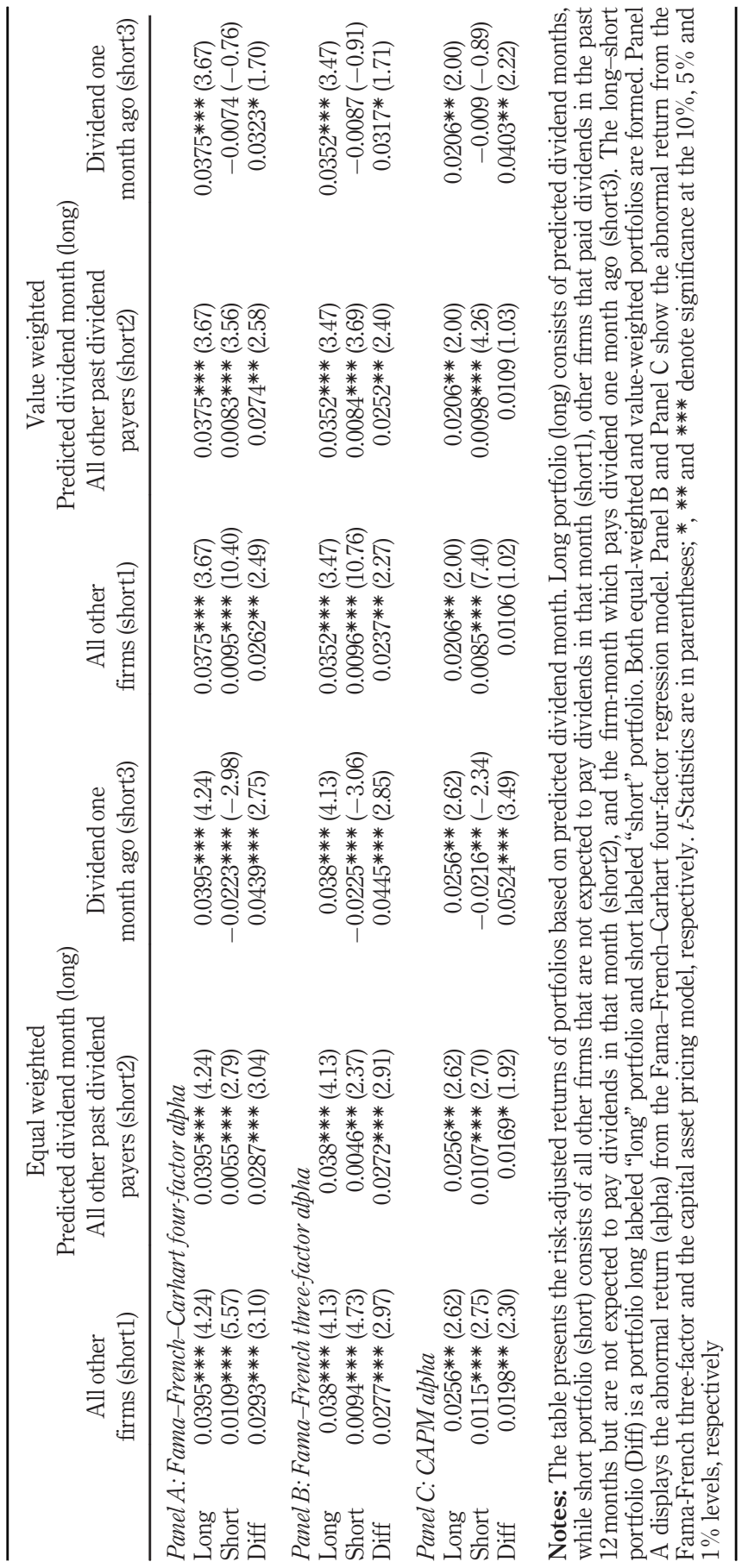




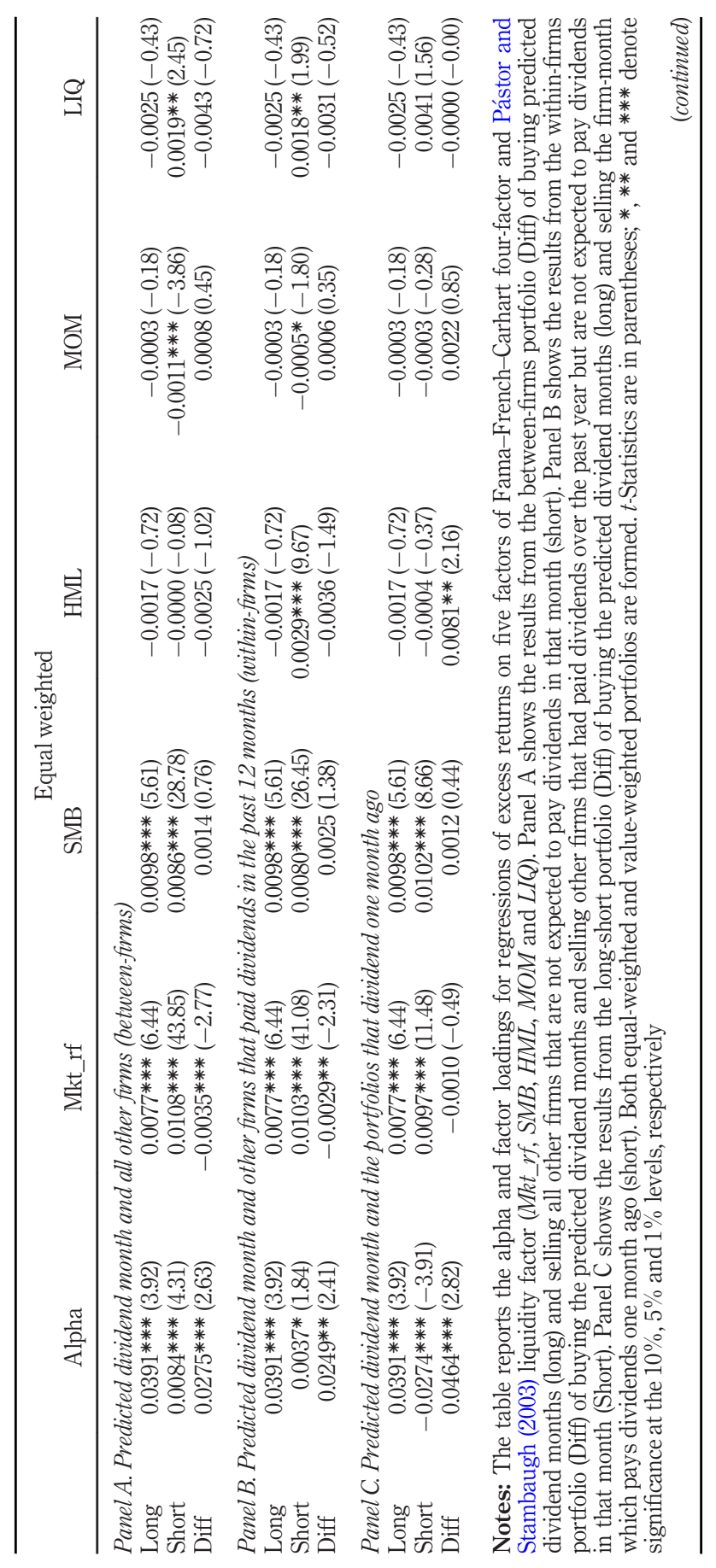

Dividend

month

premium

91

Table 6.

Risk-adjusted returns in predicted dividend month: four-factor and liquidity factor 
JDQS
28,2

92

Table 6.

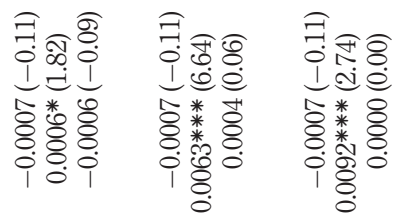

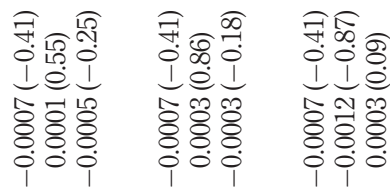

盲

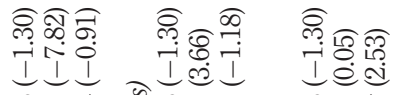

\%

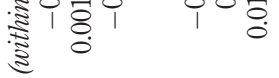

离

昰

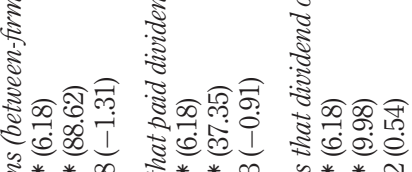

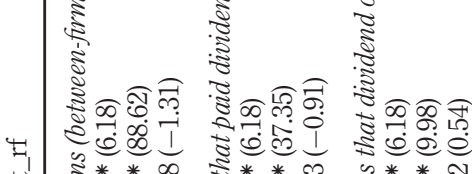

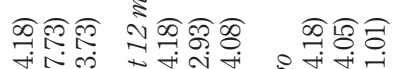

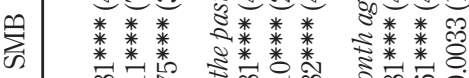

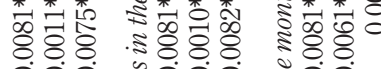

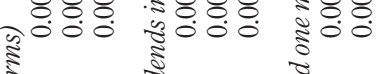

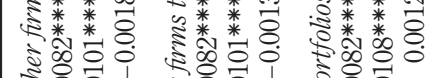

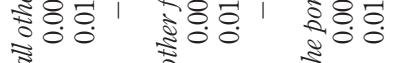

ह क्ष

छ छ छ

ㅎํำ

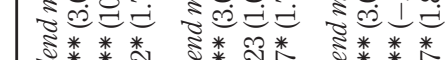

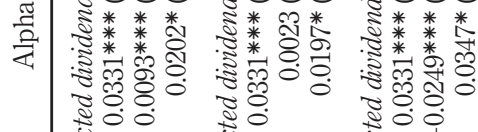

प0

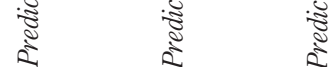

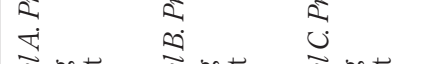

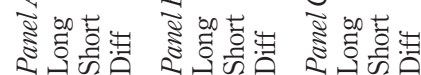




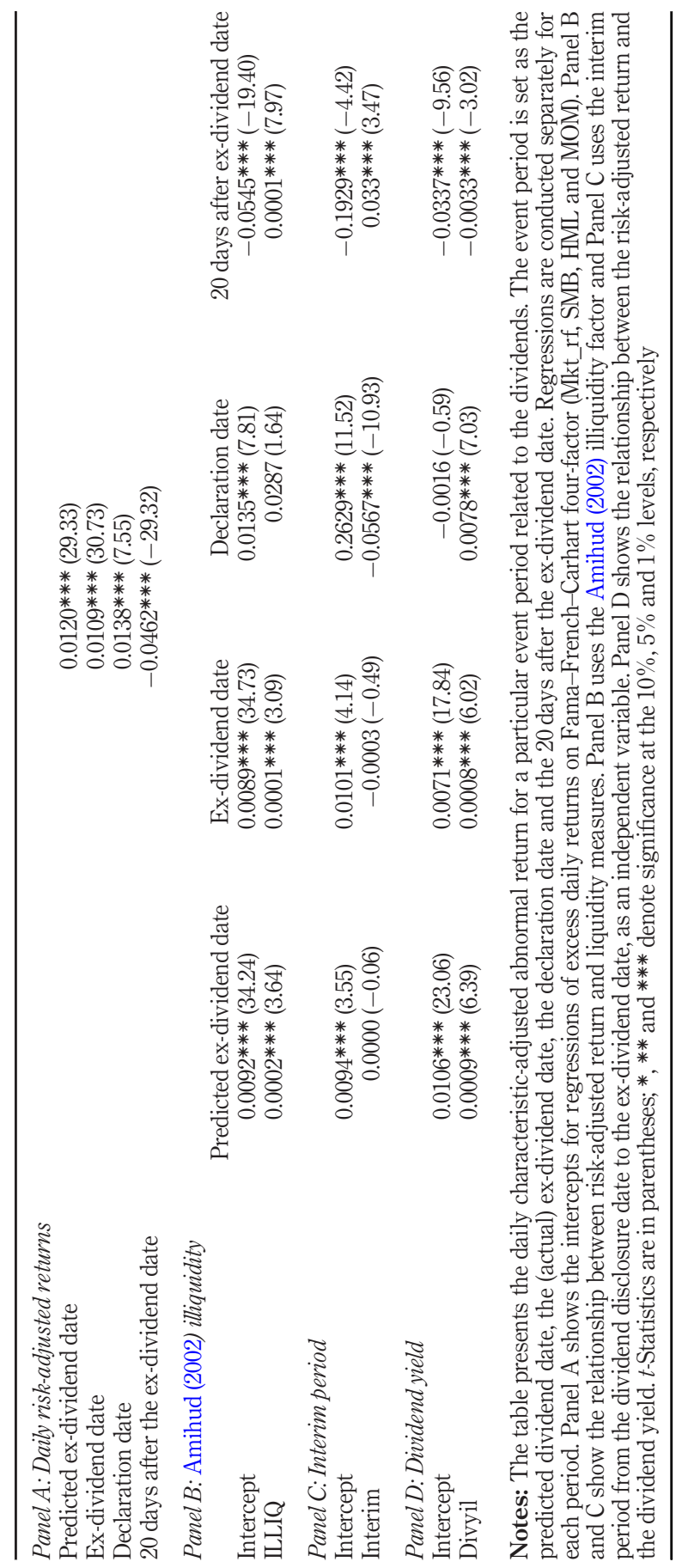

Dividend month premium

93

Table 7.

Daily characteristicadjusted returns 
JDQS

28,2

94

illiquidity is significantly positive, indicating that firms with lower liquidity generate higher abnormal returns. We test regression using equation (4) with different independent variables in Panel C and Panel D. In Panel C, we examine the relationship between riskadjusted return and liquidity using the Interim $_{i, t}$ as an independent variable instead of $I L L I Q_{i, t}$. In this test, we only use the dividend samples with pre-declaration. The results imply that the shorter the period from dividend declaration to the ex-dividend date, the higher the abnormal return on the dividend declaration date. The results from Panel B and Panel $\mathrm{C}$ are consistent with the price pressure hypothesis $H 1-2$, that less liquidity causes greater price influence for stock investors' transactions.

The relationship between the demand of dividend-seeking investors and the riskadjusted return is reported in Panel D. We test regression where $I L L I Q_{i, t}$ is replaced with Divyil $_{i, t}$ in equation (4). The coefficient on the dividend yield, which indicates the demand of dividend-seeking investors, is significantly positive on predicted dividend date and exdividend date, whereas it is a significantly negative on the cumulative return for 20 days after the ex-dividend date. This indicates that the higher the dividend yield, the higher the dividend month premium, and is consistent with the price pressure hypothesis, regarding H1-3. For further analysis of H1-3, we compare our dividend month premium with the dividend premium (BW) of Baker and Wurgler (2004). They argue that an investor's granting of a higher price to a dividend payment firm than a non-dividend payment firm is caused by higher demand for dividends. Accordingly, the dividend premium (BW) is measured as the difference between the natural log of the market-value weighted average value of the market-to-book ratio of dividend payers and nonpayers, following Baker and Wurgler (2004). Figure 2 shows the yearly average value of the dividend premium (BW) and the yearly average abnormal returns on predicted dividend month relative to the FF4 model. The two series move in a similar direction, with the correlation between the two values being 0.457 . Overall, this shows that the dividend month premium and the demand for dividends have a positive relationship and support the price pressure hypothesis.

Figure 2.

Dividend premium of Baker and Wurgler (2004)

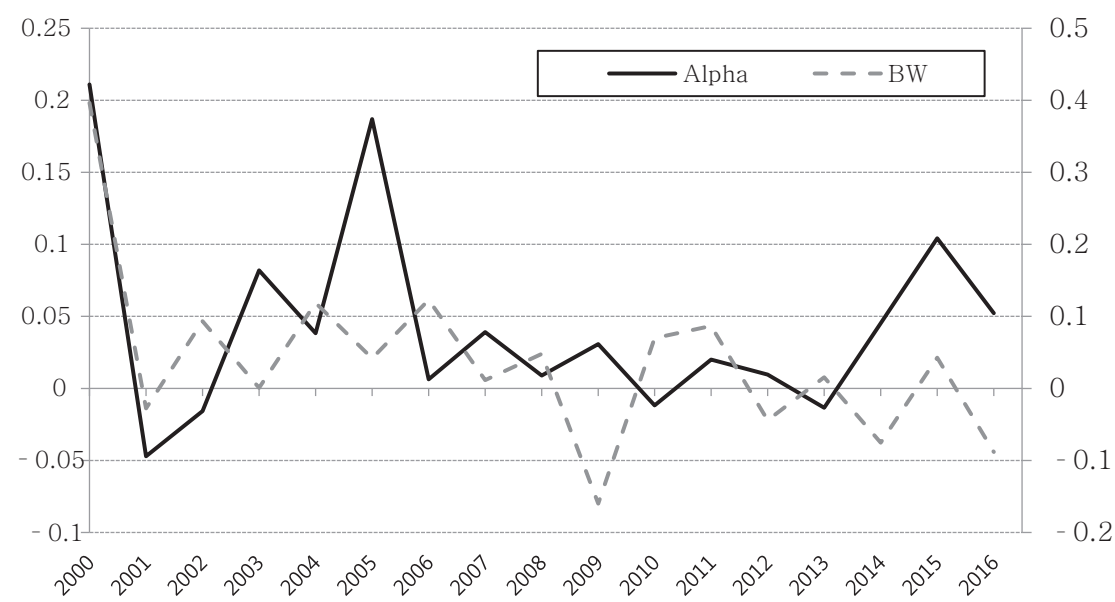

Notes: The graph compares yearly-adjusted dividend premium (BW) of Baker and Wurgler (2004) and Fama-French-Carhart four-factor alphas, from 2000 to 2016. The correlation between the two series is 0.457 
4.2.2 Dividend clientele effect. Table 7 shows that the actual ex-dividend date has significant abnormal returns of $1.09 \%$ (Panel A), a result that supports the H2-1 of dividend clientele effect. However, compared to the USA, in which more than $65 \%$ of the abnormal returns of predicted dividend months is concentrated on the ex-dividend date, the impact of the exdividend date on the predicted dividend month in Korean stock market is only $30 \%$, given that abnormal return of predicted dividend month is about $3.9 \%$. It seems that the abnormal returns of predicted dividend month do not occur over the entire period, rather it concentrates on the ex-dividend date. This can be interpreted as the dividend month premium is caused by price pressure throughout the entire predicted dividend months rather than dividend clientele effect on the dividend declaration date.

Although the dividend yield and risk-adjusted return on ex-dividend date have a positive correlation (Panel D), the risk-adjusted cumulative return after the ex-dividend date is significantly negative. This indicates return reversal, which is a violation of the H2-2 of dividend clientele effect. Figure 3 shows the risk-adjusted monthly return before and after predicted dividend months to observe a more pronounced price reversal. We display the average and cumulative abnormal return from the $\mathrm{FF} 4$ regressions model. The predicted dividend months are represented by " $0 \mathrm{~m}$," while " $-1 \mathrm{~m}$ " is one month before and " $1 \mathrm{~m}$ " is one month after predicted dividend months. We find the clear reversal pattern of negative abnormal returns one month after the predicted dividend months $(1 \mathrm{~m})$. It seems that price reversal occurs between one month before dividend and one month after, which is consistent with previous results. This implies, in general, that the dividend month premium is caused by the price pressure hypothesis rather than the dividend clientele effect.

4.2.3 Information content effect. Regarding H3-1, Panel A in Table 7 shows a significant risk-adjusted return of $1.38 \%$ at dividend declaration. However, the dividend declaration date effect only took up about $35 \%$ of the dividend month premium, given that the dividend month premium after risk adjustment is about $3.9 \%$. In addition, a significant price reversal is subsequently observed. This can be interpreted as the premium is caused by price

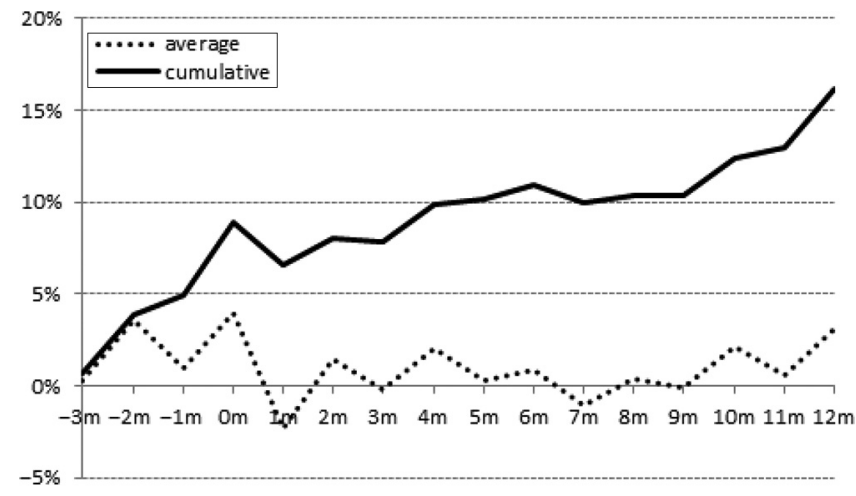

Notes: Figure 3 shows the abnormal monthly return before and after predicted dividend months using Fama-French-Carhart (1997 four-factor regression model. The graph displays both average and cumulative risk-adjusted returns. The ' $0 \mathrm{~m}$ ' refers the portfolio of dividend predicted months, while ' $-1 \mathrm{~m}$ ' is one month before and ' $1 \mathrm{~m}$ ' is one month after predicted dividend months

Figure 3. The risk-adjusted return before and after predicted dividend months 
JDQS 28,2

pressure throughout the entire predicted dividend months rather than information content effect on the dividend declaration date.

Regarding H3-2, we examine whether the dividend month premium is affected by the firm's earnings announcement in Table 8. To investigate the earnings announcement effect, we separate the samples of predicted dividend months into those with an earnings announcement and those without. The portfolios based on the predicted dividend months that do not have earnings announcement are used in Panel A. The result of Panel A which shows significant four-factor alpha indicates that earnings announcement effect cannot explain the dividend month premium. In Panel B, the long portfolio only includes the predicted dividend months that have an earnings announcement event in that month. In case the dividend predicted months coincide with earnings announcement months, there is no significant risk-adjusted return for long-short portfolios. These results contradict the US stock market which shows that the risk-adjusted return is about twice as high if dividend predicted months coincide with earnings announcement months (Hartzmark and Solomon, 2013). Although there is no clear explanation for why the significant abnormal return of long-short portfolio disappears in non-earnings months, the results from Panel A imply that the dividend month premium is not limited to earnings announcement effects.

In addition, to investigate whether the dividend month premium is specifically caused by the dividend event, we examine the relationship of a stock's abnormal return to its dividend frequency type. If the dividend month premium is generated by the dividend event, the excess return of the semi-annual dividend type should be higher only 6 or 12 months after past dividend payment. In the case of an annual dividend, the highest rate of return should significantly increase 12 months after the dividend payment. If the dividend month premium is affected by events other than dividends, the abnormal return should increase regardless of the dividend frequency type. Table 9 shows the four-factor alphas of monthly stock returns based on past dividend timing of different dividend frequency type. " $N$ months after dividend payment" means that $N$ months have passed from the month that includes the ex-dividend date. Dividend frequencies are classified into annual, semi-annual, quarterly or unknown. The quarterly dividends have higher alphas 3, 6, 9 and 12 months after dividend payments compared to other months. Semi-annual dividends also have higher returns six months after dividend payment. This indicates that such a premium only occurs in the month that corresponds to the dividend payment month by dividend type, suggesting predicted dividend months are affected by the dividend payment itself, not by other events. However, the results with annual frequency suggest that annual dividends might be caused by events other than dividends. Accordingly, additional analysis is conducted with the sample of predicted dividend months excluding annual dividends in Table 12 of robustness checks, and the results are robust.

\subsection{Pre-declaration and post-declaration}

In the case of pre-and post-declaration, there are differences in the information content effect from the perspective of investors (Khil and Han, 2018). Accordingly, we calculate separate four-factor alphas of monthly stock returns based on dividend procedure. The results of Panel A in Table 10 show that predicted dividend month with pre-declaration have significant abnormal returns and subsequent price reversals. This suggests that the dividend month premium occurs even when the information content effect is relatively high, resulting in more clear evidence that contradicts weak-form EMH. Also, post-declaration firms show a higher abnormal return compared to pre-declaration. The four-factor alpha on post-declaration firms' predicted dividend months is 3.82\%, compared with $3.69 \%$ for predeclaration firms. The within-firms portfolio analysis also shows higher four-factor alpha of 


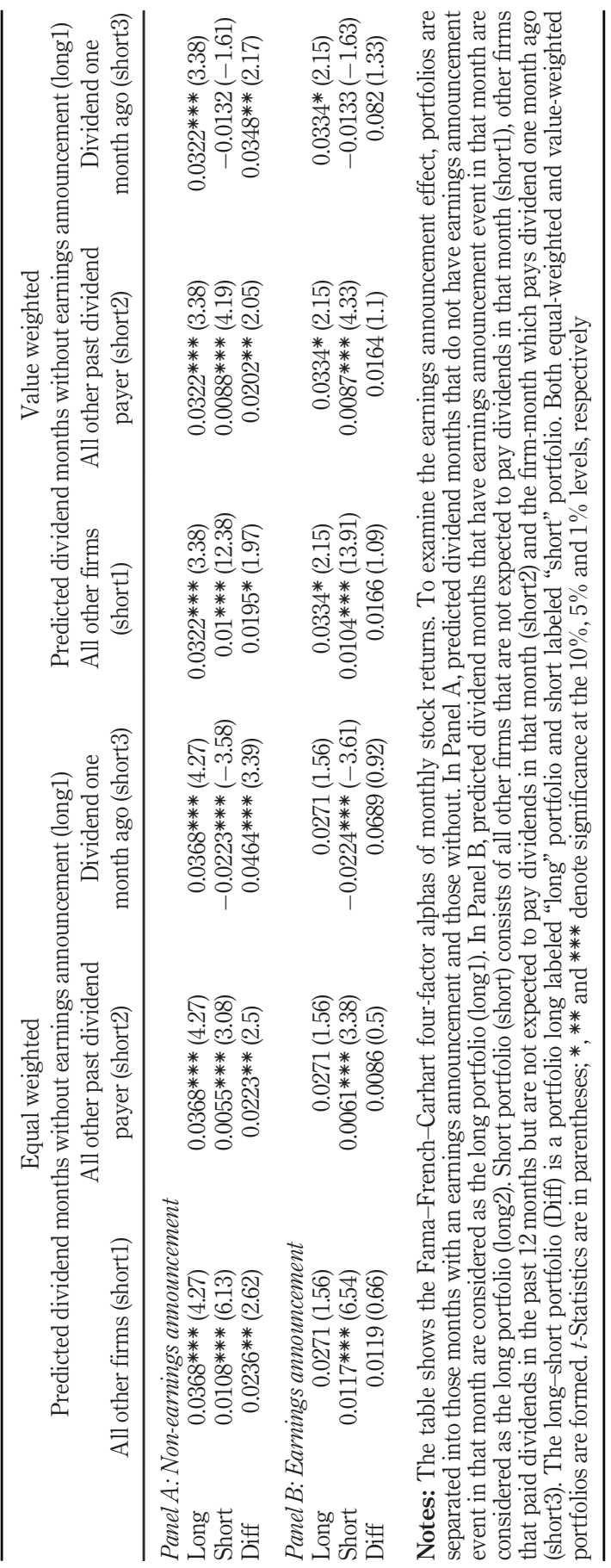

Dividend month premium

Table 8.

Earnings announcement effect 
JDQS

28,2

98

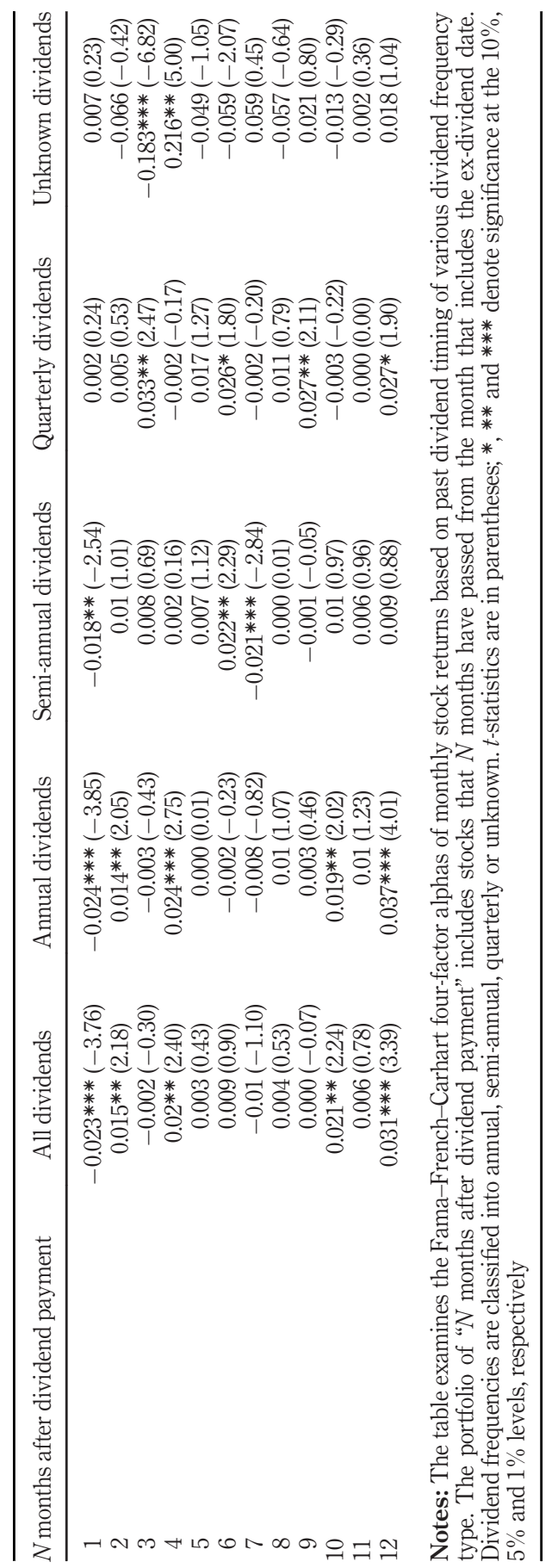

Table 9.

Dividend frequency and the risk-return of past dividend timing 


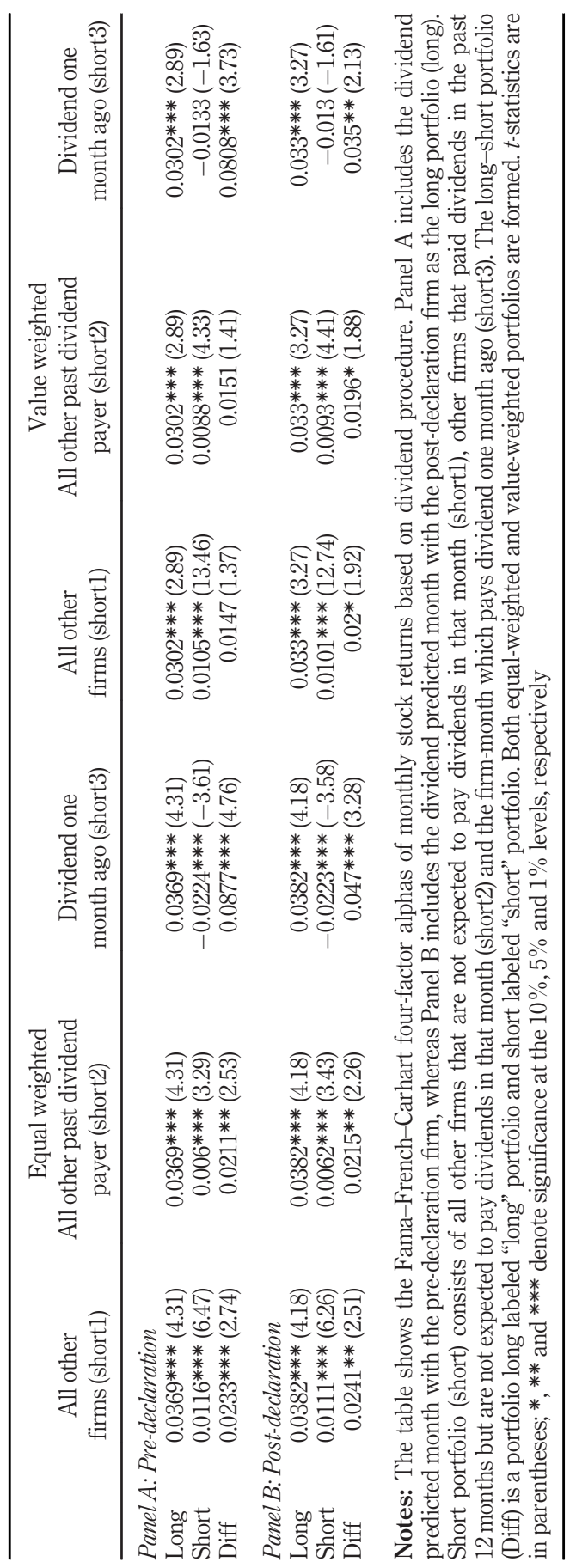

Dividend month premium

99

Table 10

Pre-declaration and post-declaration 
JDQS 28,2

100

$2.15 \%(t$-values $=2.26)$ for post-declaration firms than the $2.11 \%(t$-values $=2.56)$ for predeclaration firms. The dividend month premium for post-declaration firms is higher because of the increased uncertainty of investors because of the relatively low information content effect.

\subsection{Firm-characteristics}

Because the abnormal returns of the predicted dividend months may be affected by the characteristics of the firm, we separate our sample into two groups according to their characteristics. Panel A in Table 11 classifies the possibility of dividends into high and low groups based on the number of observations of past consecutive dividends, whereas Panel B classifies the age of firms into old and young, depending on the initial year of observation. The results indicate that the firms with a higher possibility of dividend and older firm, the lower the abnormal returns. Although the firm size and book-to-market ratio are controlled through the FF4 models in most analysis, Panel C classifies firm size into large and small groups based on market capitalization and Panel D classifies firms into high and low groups based on their book-to-market ratio to analyze the differences between the characteristics of firms within the predicted dividend months. It shows that abnormal return gets larger with

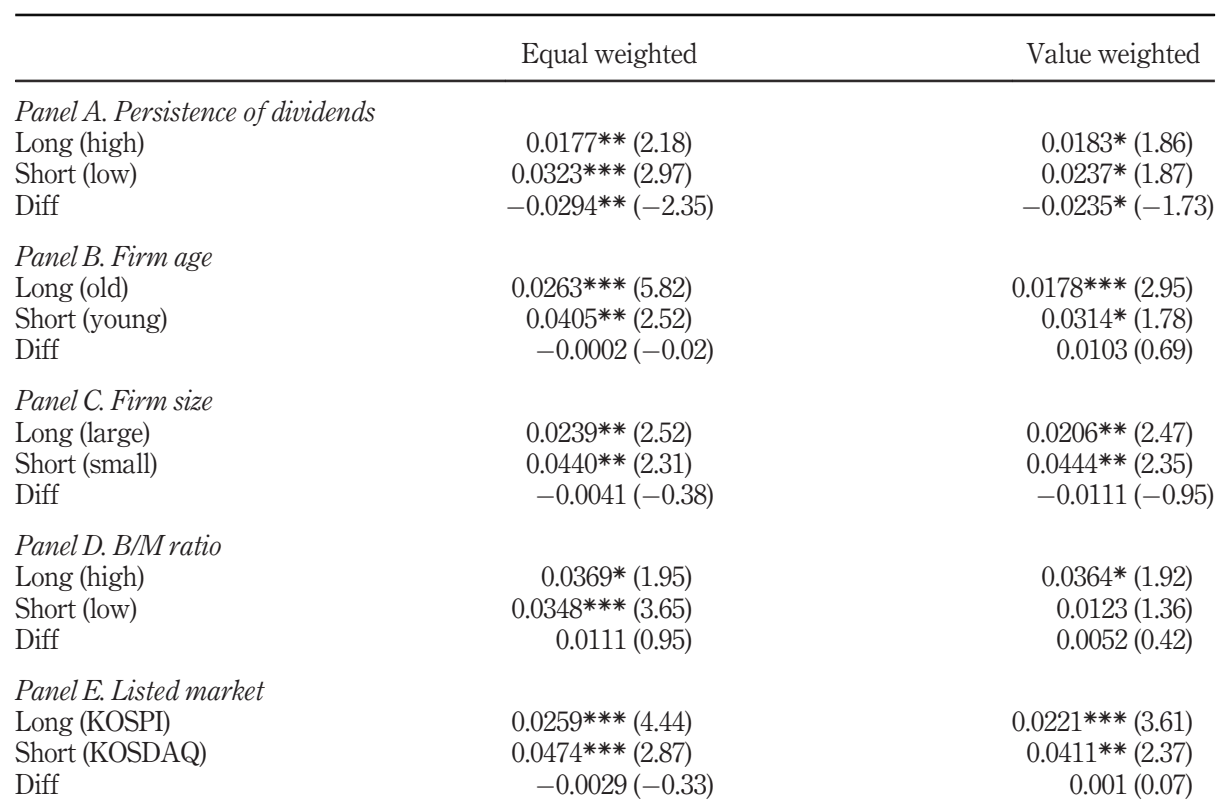

Table 11.

Risk-adjusted return based on firmcharacteristics
Notes: The table presents the Fama-French-Carhart four-factor alphas of monthly stock returns based on firm-characteristics. Panel A splits the portfolios of the dividend predicted month into two groups based on the persistence of dividends, measured by the number of observations of past consecutive dividends. Panels B, C, D and E separate the portfolios into two groups based on the age of firms, the firm size, the book-tomarket ratio and the listed market, respectively. Each firm-month is sorted according to whether they are above or below the median value for this variable in that month. The long-short portfolio (Diff) is a portfolio that buying the portfolios in the top row and selling the portfolios in the bottom row. Both equalweighted and value-weighted portfolios are formed. $t$-statistics are in parentheses; $*$, ** and *** denote significance at the $10 \%, 5 \%$ and $1 \%$ levels, respectively 


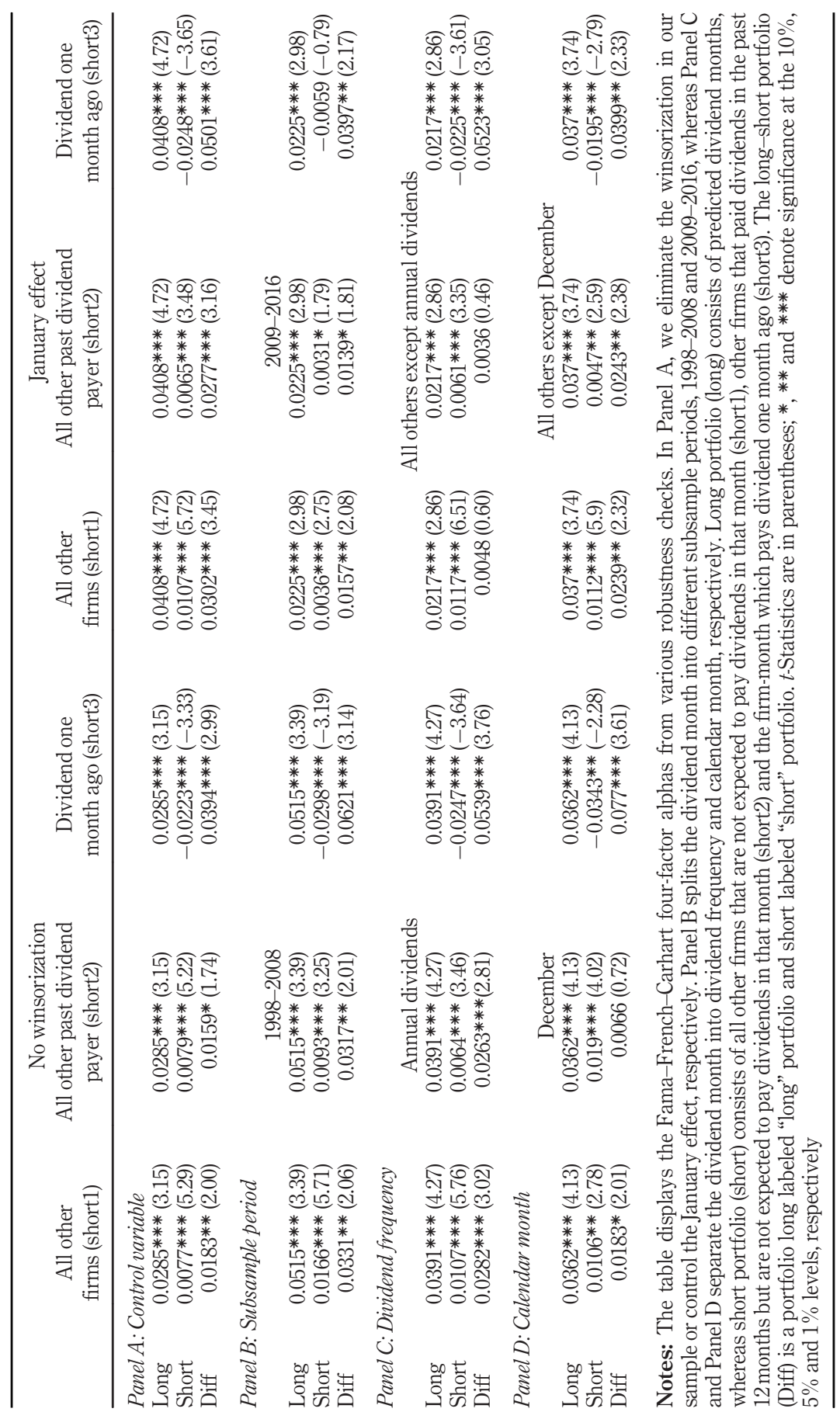

Dividend month premium

101

Table 12 Robustness checks 
JDQS 28,2

the smaller firm and the higher the book-to-market ratio. In Panel E, when examining the difference in abnormal returns between KOSPI-listed firms and KOSDAQ-listed firms, it seems that KOSDAQ-listed firms, which have less liquidity, have higher abnormal returns than KOSPI-listed firms. Overall, the firms with relatively less liquidity have a larger impact in predicted dividend month, which supports the price pressure hypothesis.

\section{2}

\subsection{Robustness test}

Table 12 displays the results from various robustness checks. It shows the FF4 alphas of monthly stock returns based on predicted dividend month. We eliminate the winsorization in our sample and a January dummy variable is added to control for the January effect in Panel A. Also, Panel B divides the subsample period into early (1998-2008) and late period (2009-2016) to verify the dividend month premium evenly occurring over the entire sample period, rather than occurring only at a certain period. Considering much of the dividend frequency in Korea is annual, Panel $\mathrm{C}$ examines abnormal returns by separating the case including annual-dividend and excluding annual-dividend. As most firms in Korea have the December settlement, we examine the excess return of predicted dividend months by distinguishing the case including December and excluding December. Accordingly, Panel D analyzes cases in which the predicted dividend months are in December and those in other months. Both the coefficients and significance are robust in Table 12.

\section{Conclusion}

Investors can predict the next dividend payment by using the firm's characteristics that are reluctant to omit dividends (Kalay and Loewenstein, 1986; Eades et al., 1985; Nissim and Ziv, 2001). If dividend payments are predictable using historical information, the abnormal return of predicted dividend months is a violation of EMH. Especially, the prediction of dividend payment is important in Korea, because post-declaration procedures of cash dividends make dividend-seeking investors trade shares based on forecasts of dividend payments.

We find that the dividend month premium reverses later. This premium gets larger with lower liquidity or higher dividend yield. In addition, the abnormal return gets higher if the number of past consecutive dividends is smaller, the firm size is smaller and the book-tomarket ratio is higher. Overall, this suggests that the dividend month premium is because of price pressure from dividend-seeking investors.

The dividend month premium is higher when the dividend is post-declaration than when it is pre-declaration. This suggests that the post-declaration procedure has an influence on the dividend month premium, and temporarily undermines market efficiency. Improvements in the cash dividend procedure are needed to reduce investors' uncertainty regarding dividend and ultimately enhance market efficiency.

\section{Notes}

1. Under domestic commercial law, stock dividends or interim cash dividends are subject to predeclaration, but fiscal-year cash dividends are subject to post-declaration. Voluntary predeclaration is also possible for cash dividends, but only about $4 \%$ of the dividend samples for common shares are pre-declared from 1999 to 2016.

2. According to the weak-form EMH (Fama, 1970), all information is immediately reflected in the share price, and abnormal returns cannot be gained even based on an investment strategy from past information. 
3. The price pressure theory does not directly explain changes in demand for dividend-paying stocks by investors, but the dividend catering theory and dividend clientele theory support this. According to the dividend catering theory, investors prefer to buy dividend-paying shares immediately before the ex-dividend date instead of after because investors have potential demand for dividends based on psychological reasons (Baker and Wurgler, 2004).

4. For months other than the declaration date, there is no clear explanation for why firms are exposed to different risks, but it is argued that there is some explanation based on liquidity.

5. The Sharpe ratio is calculated by subtracting the risk-free rate from the average return of portfolio, then dividing this excess return by the standard deviation of the portfolio's excess return. We use CD91 yield as the risk-free rate.

6. If the analysis is carried out in two steps without conducting a simultaneous regression analysis of FF4 model and other explanatory factors, as shown above, the explanatory factors and the FF4 factor model will be mutually independent and thus a clearer analysis will be possible, which is why we conduct above method.

7. However, the regression analysis measured on the basis of shares with at least 100 observations over the past year.

\section{References}

Amihud, Y. (2002), "Illiquidity and stock returns: cross-section and time-series effects", Journal of Financial Markets, Vol. 5 No. 1, pp. 31-56.

Amihud, Y. and Mendelson, H. (1986), "Asset pricing and the bid-ask spread”, Journal of Financial Economics, Vol. 17 No. 2, pp. 223-249.

Arnott, R.D. and Asness, C.S. (2003), "Surprise! Higher dividends = higher earnings growth", Financial Analysts Journal, Vol. 59 No. 1, pp.70-87.

Baik, B., Kim, Y.J. and Lee, J. (2012), "A study on the exact timing of annual earnings announcements in the Korean market", Korean Accounting Review, Vol. 37 No. 4, pp. 253-293.

Baker, M. and Wurgler, J. (2004), “A catering theory of dividends”, The Journal of Finance, Vol. 59 No. 3, pp. 1125-1165.

Beaver, W.H. (1968), "The information content of annual earnings announcements", Journal of Accounting Research, Vol. 6, pp. 67-92.

Bessembinder, H. and Zhang, F. (2015), "Predictable corporate distributions and stock returns", The Review of Financial Studies, Vol. 28 No. 4, pp. 1199-1241.

Brennan, M.J. (1970), “Taxes, market valuation and corporate financial policy”, National Tax Journal, Vol. 23 No. 4, pp. 417-427.

Brennan, M.J., Chordia, T. and Subrahmanyam, A. (1998), "Alternative factor specifications, security characteristics, and the cross-section of expected stock returns", Journal of Financial Economics, Vol. 49 No. 3, pp. 345-373.

Carhart, M.M. (1997), "On persistence in mutual fund performance”, The Journal of Finance, Vol. 52 No. 1 , pp. 57-82.

Eades, K.M., Hess, P.J. and Kim, E.H. (1985), "Market rationality and dividend announcements”, Journal of Financial Economics, Vol. 14 No. 4, pp. 581-604.

Elton, E.J. and Gruber, M.J. (1970), "Marginal stockholder tax rates and the clientele effect", The Review of Economics and Statistics, Vol. 52 No. 1, pp. 68-74.

Fama, E.F. (1970), "Efficient capital markets: a review of theory and empirical work", The Journal of Finance, Vol. 25 No. 2, pp. 383-417. 
Fama, E.F. and French, K.R. (1993), "Common risk factors in the returns on stocks and bonds", Journal of Financial Economics, Vol. 33 No. 1.

Harris, L.E., Hartzmark, S.M. and Solomon, D.H. (2015), "Juicing the dividend yield: mutual funds and the demand for dividends", Journal of Financial Economics, Vol. 116 No. 3, pp. 433-451.

Hartzmark, S.M. and Solomon, D.H. (2013), “The dividend month premium”, Journal of Financial Economics, Vol. 109 No. 3, pp. 640-660.

Kalay, A. and Loewenstein, U. (1985), "Predictable events and excess returns: the case of dividend announcements", Journal of Financial Economics, Vol. 14 No. 3, pp. 423-449.

Kalay, A. and Loewenstein, U. (1986), "The informational content of the timing of dividend announcements", Journal of Financial Economics, Vol. 16 No. 3, pp. 373-388.

Khil, J. and Han, S. (2018), "Stock returns on ex-dividend date: advance disclosure and ordinary disclosure", Journal of Korea Academia-Industrial Cooperation Society, Vol. 15 No. 3, pp. 111-128.

Lintner, J. (1956), "Distribution of incomes of corporations among dividends, retained earnings, and taxes", The American Economic Review, Vol. 46 No. 2, pp. 97-113.

Miller, M.H. and Modigliani, F. (1961), "Dividend policy, growth, and the valuation of shares", The Journal of Business, Vol. 34 No. 4, pp. 411-433.

Nissim, D. and Ziv, A. (2001), "Dividend changes and future profitability", The Journal of Finance, Vol. 56 No. 6, pp. 2111-2133.

Pástor, L. and Stambaugh, R.F. (2003), "Liquidity risk and expected stock returns”, Journal of Political Economy, Vol. 111 No. 3, pp. 642-685.

Savor, P. and Wilson, M. (2016), "Earnings announcements and systematic risk", The Journal of Finance, Vol. 71 No. 1, pp. 83-138.

\section{Corresponding author}

Joon Chae can be contacted at: joonchae@snu.ac.kr

For instructions on how to order reprints of this article, please visit our website: 